\title{
Passive and active immunity of broiler chickens against Campylobacter jejuni and ways of disease transmission
}

\author{
Silvia Ondrašovičová ${ }^{1}$, Monika Pipová $^{2}$, Petr Dvořák ${ }^{3}$, Monika Hričínová4, \\ Rudolf Hromada ${ }^{5}$, Jozef Kremeň ${ }^{5}$
}
${ }^{1}$ Department of Anatomy, Histology and Physiology, ${ }^{2}$ Department of Food Hygiene and Technology, University of Veterinary Medicine and Pharmacy, Košice, Slovak Republic
${ }^{3}$ Department of Biochemistry, Biophysics and Chemistry, Faculty of Veterinary Hygiene and Ecology,
University of Veterinary and Pharmaceutical Sciences Brno, Czech Republic
${ }^{4}$ Department of Microbiology and Immunology, University of Veterinary Medicine and Pharmacy, Košice, Slovak Republic
${ }^{5}$ Department of Environment, Veterinary Legislation and Economics, University of Veterinary Medicine and Pharmacy, Košice, Slovak Republic

Received June 7, 2010

Accepted March 7, 2012

\begin{abstract}
The study deals with passive and active immunity of fifty-three broiler chickens after infection with culture of Campylobacter jejuni. Potential transfer of infection by faecal-oral and aerogenic routes was also investigated. Cloacal swabs and ceacal content were analyzed microbiologically. Identification of $C$. jejuni was carried out by polymerase chain reaction. Observation of passive immunity of broilers from 3 days of age showed that no transfer of $C$. jejuni infection occurred up to 12 day post-infection (p.i.). Observations of active immunity in fourteen 21 days old chickens infected with $C$. jejuni showed that 6 chickens were positive on day 3 p.i. and all infected chickens were positive on day 5 p.i. Investigations of the transfer of C. jejuni by faecal-oral route revealed positivity in two broilers on day 3 p.i. and in all tested chickens on day 5 p.i. Aerogenic transfer of infection was not recorded. This was one of the first studies in our country dealing with passive and active immunity of broiler chickens against $C$. jejuni and spreading of this zoonotic disease.
\end{abstract}

Campylobacteriosis, PCR, microbiological examination, disease transfer

The food chain is considered one of the most important ways of transfer of alimentary infections among animals and humans. The spreading of infections in poultry production is related to insufficient hygiene of rearing which is stressful to housed birds and results in increased numbers of heterophils (Bedáňová et al. 2007).

Campylobacter jejuni is world-wide considered the principal cause of human diarrhoeal diseases and gastroenteritis transmissible in food. Campylobacteriosis is a zoonosis; many animals serve as reservoirs of this infectious disease. Campylobacter sp. enters the environment also via drinking water contaminated with excrements of animals, birds or infected people (Nogva et al. 2000).

The aim of the study was to investigate passive and active immunity of broiler chickens against $C$. jejuni and potential transfer of this disease by faecal-oral and aerogenic routes.

\section{Materials and Methods}

Experimental animals

Fifty-three broiler chickens of the Ross 308 hybrid were obtained from an approved hatchery Častá (No. SK-LH-PK-01-MACH poultry, Budmerice s.r.o., Slovak Republic). The chickens were kept in the experimental facilities of the Department of Microbiology and Immunology, University of Veterinary Medicine and Pharmacy (UVMP) in Košice.

Before the experiment, cloacal swabs were taken from all chickens included in the study and all were negative for Campylobacter sp. Then, after 2 days of acclimatization, they were assigned to four experimental groups: Group $1(\mathrm{n}=13)$, Group $2(\mathrm{n}=20)$, Groups $3(\mathrm{n}=10)$ and Group $4(\mathrm{n}=10)$.

Address for correspondence:

MVDr. Silvia Ondrašovičová, PhD.

Department of Anatomy, Histology and Physiology

University of Veterinary Medicine and Pharmacy

Komenského 73, 04181 Košice, Slovak Republic
Phone: 532146205

Fax: 541211214

E-mail: ondrasov1@uvm.sk

http://actavet.vfu.cz/ 
Infection

To infect the chickens we administered bacterial culture of reference strain of C. jejuni CCM 6207 (Masaryk University Brno, Czech Republic) per os at a dose of $0.2 \mathrm{ml}$ per experimental chick. The colony-forming unit $(\mathrm{CFU})$ counts at testing of passive and active immunity were $10^{3} \cdot \mathrm{ml}^{-1}$ and $10^{4} \cdot \mathrm{ml}^{-1}$, respectively.

Seven chicks from Group 1 were infected with C. jejuni at the age of 3 days, to evaluate their passive immunity. For evaluation of active immunity we infected 14 chickens from Group 2 at the age of 21 days with the same culture of $C$. jejuni. The remaining six chickens of Groups 1 and 2 were not infected and were housed together with the infected ones to observe potential transfer by the faecal-oral route. Group 3 was kept in a separate cage in the same experimental room to observe the possibility of aerogenic transfer. Group 4 was housed in a separate room and served as control.

In the first week of age the chickens were exposed to a temperature of $25-30{ }^{\circ} \mathrm{C}$ which was then decreased to 22-27 ${ }^{\circ} \mathrm{C}$. Standard mixed feed BR1, BR2 and BR3 was supplied to the chickens according to the age. They were fed ad libitum from a feeder and had free access to drinking water.

Sampling and microbiological diagnosis

Using sterile swabs, two cloacal samples were taken from all broilers on predetermined days (Tables 1 and 2). One swab was transferred to a tube with Bolton liquid multiplication medium and incubated under micro-aerobic conditions for 4 to $6 \mathrm{~h}$ at $37^{\circ} \mathrm{C}$ and then for $44 \mathrm{~h} \pm 4 \mathrm{~h}$ at $41.5^{\circ} \mathrm{C}$. After incubation, we inoculated a loopful of the culture onto two selective modified media, mCCDA and Skirrow agar medium.

The second cloacal swab was used to inoculate directly the mCCDA and Skirrow agar media. The inoculated media were incubated at $41.5^{\circ} \mathrm{C}$ under micro-aerobic conditions and the colonies were counted after $44 \mathrm{~h} \pm 4 \mathrm{~h}$. The procedures used for confirmation of the genus Campylobacter and for differential diagnostics complied with the Slovak standard STN EN ISO 10272-1.

The broilers were killed by cervical dislocation on predetermined days (Tables 1 and 2). Determination of Campylobacter was carried out on $1 \mathrm{~g}$ of the caecal sac content using decimal dilutions (ISO/TS 10272-2, Slovak standard STN EN ISO 10272-1).

\section{PCR diagnosis}

The DNA was isolated from $C$. jejuni colonies grown on the above described selective solid media by resuspending them in $500 \mu \mathrm{l}$ sterile distilled water and incubation at $100{ }^{\circ} \mathrm{C}$ for $5-20 \mathrm{~min}$. The sample was then centrifuged at $12000 \mathrm{~g}$ for $5 \mathrm{~min}$ (twice) and the supernatant was used for PCR. Concentration of the DNA was determined by a spectrophotometer Spectronic Genesys 5. For PCR we used $100 \mathrm{ng}$ of DNA of the examined sample, $5 \mu \mathrm{l}$ of $10 \times$ concentrated buffer solution according to manufacturer's recommendation, $0.2 \mathrm{mM} \mathrm{dNTPs}$, $1 \mu \mathrm{M}$ primers, $3.5 \mathrm{mM} \mathrm{MgCl}, 1.0 \mathrm{U}$ AmpliTaq DNA Polymerase (Perkin Elmer, USA). The sample volume was made up to $50 \mu \mathrm{l}$ with distilled water. The primers for genus Campylobacter were C412F and C1228R, resulting

Table 1. Testing of passive immunity and potential faecal-oral infection transfer in broilers from Group 1.

\begin{tabular}{cccc}
\hline \multirow{2}{*}{$\begin{array}{c}\text { Number of } \\
\text { birds }\end{array}$} & \multicolumn{3}{c}{ Microbiological examination of cloacal swabs and caecal sacs } \\
\cline { 2 - 4 } & Day $3,5,7$ & Day 9 p.i. & Day 12 p.i. \\
\hline 1 & Infected with C. jejuni (passive imunity) & \\
2 & - & $-*$ & \\
3 & - & $-*$ & \\
4 & - & $-*$ & $-*$ \\
5 & - & - & $-*$ \\
6 & - & - & $-*$ \\
7 & - & - & $-*$ \\
8 & - & - & \\
9 & Non infected (faecal-oral transfer) & \\
10 & - & $-*$ & $-*$ \\
11 & - & $-*$ & $-*$ \\
12 & - & $-*$ & $-*$ \\
13 & - & - & - \\
\hline
\end{tabular}

*collection of samples from caecal sacs after slaughtering the chickens in an amplicon $816 \mathrm{bp}$ and the primers for species $C$. jejuni were Jej1F and Jej2R, resulting in an amplicon 793 bp (Brown et al. 2004). To identify PCR products we used system GelLogic 100.

The results obtained were evaluated statistically using one-way ANOVA, Friedman test, Dunn's post-test and Mann-Whitney test.

\section{Results}

The tests of passive
immunity of 3-day-old
chickens infected with $C$. jejuni (Group 1) carried out on days $3,5,7,9$ and 12 post-infection (p.i.), provided negative results for Campylobacter (Table 1). Throughout the experiment we observed no health changes in the experimental chickens.

The testing of active 
Table 2. Testing of active immunity and potential faecal-oral infection transfer in broilers from Group 2

\begin{tabular}{|c|c|c|c|c|}
\hline \multirow{2}{*}{$\begin{array}{l}\text { Number } \\
\text { of birds }\end{array}$} & \multicolumn{4}{|c|}{ Microbiological and PCR examination of cloacal swabs and caecal sacs } \\
\hline & Day 3 p.i & Day 5,7 p.i. & Day 9 p.i. & Day 12 p.i. \\
\hline & \multicolumn{4}{|c|}{ Infected with $C$. jejuni (active imunity) } \\
\hline 1 & - & + & $+*$ & \\
\hline 2 & - & + & $+*$ & \\
\hline 3 & - & + & $+*$ & \\
\hline 4 & - & + & $+*$ & \\
\hline 5 & - & + & $+*$ & \\
\hline 6 & - & + & $+*$ & \\
\hline 7 & + & + & $+*$ & \\
\hline 8 & + & + & + & $+*$ \\
\hline 9 & + & + & + & $+*$ \\
\hline 10 & + & + & + & $+*$ \\
\hline 11 & + & + & + & $+*$ \\
\hline 12 & + & + & + & $+*$ \\
\hline 13 & - & + & + & $+*$ \\
\hline \multirow[t]{2}{*}{14} & - & + & + & $+*$ \\
\hline & \multicolumn{4}{|c|}{ Non infected (faecal-oral transfer) } \\
\hline 15 & - & + & $+*$ & \\
\hline 16 & - & + & $+*$ & \\
\hline 17 & + & + & $+*$ & \\
\hline 18 & - & + & + & $+*$ \\
\hline 19 & + & + & + & $+*$ \\
\hline 20 & - & + & + & $+*$ \\
\hline
\end{tabular}

*sampling of caecal sacs after slaughter examination. Two slaughtered chickens infected with $C$. jejuni showed dilatation of jejunum. On day 12 p.i. additional three chickens from this group, infected with $C$. jejuni, were affected with diarrhoea. All remaining chickens were slaughtered on this day. Post mortem examination showed dilatation of jejunum in four infected chickens and disseminated haemorrhagic enteritidis in one of them.

The plate counts of C. jejuni in $1 \mathrm{~g}$ of caecal content of infected chickens (Group 2) ranged from $3.6 \times 10^{5}$ to $5.1 \times 10^{6} \mathrm{CFU}$ and in chickens infected by the faecal-oral route from $7.4 \times 10^{4}$ to $4.3 \times 10^{6} \mathrm{CFU}$.

Their body mass in Group 2 ranged between $0.9 \mathrm{~kg}$ and $1.2 \mathrm{~kg}$ (mean $0.98 \mathrm{~kg}$ ).

Statistical evaluation of the day of colonization of intestinal tract with $C$. jejuni in Group 2 by means of transformation 0 (negative) and 1 (positive) by Friedman test and Dunn's post-test showed significant difference between days 1 and 5 p.i. at the level of significance $\alpha=0.01$. Evaluation of findings by Mann-Whitney test on day 3 p.i. in Group 2 comparing the spreading of infection by direct and faecal-oral route showed no significant differences $(\alpha=0.05)$ meaning that the infection spread at the same rate.

The cloacal swabs taken from all chickens from Groups 3 and 4 on days 3, 7, 17 and 33 of the experiment were negative for $C$. jejuni. The health of these chickens was good throughout the experiment. The body mass of chickens from Group 3 ranged between 1.3 and $1.7 \mathrm{~kg}$ and that of chickens from Group 4 between 1.3 and $1.9 \mathrm{~kg}$ but the mean body mass was the same in both groups $(1.5 \mathrm{~kg})$. 


\section{Discussion}

PCR methods have been frequently used to diagnose agents of human (Jautová et al. 2001) and animal diseases (Holoda et al. 2005).

Microbiological and PCR methods used in our study showed that all investigated broiler chickens from Group 1 were negative for $C$. jejuni up to slaughter (12 and 15 days of age). This could be ascribed to the high concentration of circulating maternal specific antibodies that confer passive immunity and start to decrease only after 14 days of age (Sahin et al. 2001).

All broiler chickens infected in our study with $C$. jejuni at the age of 21 days (Group 2) were positive for $C$. jejuni. The faecal-oral route of infection transfer was confirmed. The infection spread at the same rate by both direct and faecal-oral route by day 3 p.i., as witnessed by Mann-Whitney test $(\alpha=0.05)$. No aerogenic transfer of infection was observed.

Previous observations (Mead et al. 1995) showed that colonization of $1 \mathrm{~g}$ of caecal content with Campylobacter during fattening of broiler chickens reached $10^{7} \mathrm{CFU}$. The C. jejuni counts determined in our experiment (Group 2) were lower.

The body mass of chickens of the Ross 308 hybrid reaches approximately $1.8 \mathrm{~kg}$ at the age of 32 days (Havenstein et al. 2003). The weight gain of chickens involved in the present study of active immunity of chickens (Group 2) infected with $C$. jejuni was lower.

\section{References}

Bedáňová I, Voslářová E, Večerek V, Pištěková V, Chloupek P 2007: Haematological profile of broiler chickens under acute stress dues to shackling. Acta Vet Brno 76: 129-135

Brown PE, Christensen OF, Clough HE, Diggle PJ, Hart, CA, Hazel S, Kemp R, Leatherbarrow AJH, Moore A, Sutherst J, Turner, J, Williams NJ, Wrihgt EJ, French, NP 2004: Frequency and spatial distribution of environmental Campylobacter spp. Appl Environ Microbiol 70: 6501-6511

Havenstein GB, Ferket PR, Qureshi MA 2003: Carcass composition and yield of 1957 versus 2001 broilers when fed representative 1957 and 2001 broiler diets. Poultry Sci 82: 1509-1518

Holoda E, Vu-Khac, H, Andrašková S, Chomová Z, Wantrubová A, Krajňák M, Pilipčinec E 2005: PCR assay for detection and differentiation of K88ab1, K88ab2, K88ac and K88ad fimbrial adhesins in E.coli strains isolated from diarrheic piglets. Folia Microbiol 50: 107-112

ISO/TS 10272:2006 Microbiology of food and feed. Horizontal method for confirmation and determination of plate counts of bacteria Campylobacter. Part 2: Determination of plate counts (Mikrobiológia potravín a krmív. Horizontálna metóda na dôkaz a stanovenie počtu baktérií Campylobacter. Čast' 2: Stanovenie počtu) (In Slovak)

Jautová J, Virágová S, Ondrašovič M, Holoda E 2001: Incidence of Candida species isolated from human skin and nails: a survey. Folia Microbiol 46: 333-337

Mead GC, Hutson WR, Hinton MH 1995: Effect of changes in processing to improve hygiene control on contamination of poultry carcasses with Campylobacter. Epidemiol Infect 115: 495-500

Nogva HK, Bergh A, Holck A, Rudi K 2000: Application of the 5'-nuclease PCR assay in evaluation and development of methods for quantitative detection of Campylobacter jejuni. Appl Environ Microbiol 66: 4029-4039

Sahin O, Zhang Q, Meitzler JC, Harr BS, Morishita TY, Mohan R 2001: Prevalence, antigenic specificity, and bactericidal activity of poultry anti-Campylobacter maternal antibodies. Appl Environ Microbiol 67: 3951-3957

STN EN ISO 10272:2006 Microbiology of food and feed. Horizontal method for confirmation and determination of plate counts of bacteria Campylobacter. Part 1: Confirmation method (Mikrobiológia potravín a krmív. Horizontálna metóda na dôkaz a stanovenie počtu baktérií Campylobacter. Čast' 1: Metóda dôkazu) (In Slovak). SÚTN, Bratislava 